\title{
Resource degradation of the sea cucumber fishery in Zanzibar, Tanzania: a need for management reform
}

\author{
B. Hampus Eriksson ${ }^{1, a}$, Maricela de la Torre-Castro ${ }^{1,2}$, Johan Eklöf ${ }^{1}$ and Narriman Jiddawi ${ }^{3}$ \\ 1 Department of Systems Ecology, Stockholm University, SE-106 91 Stockholm, Sweden \\ 2 Institute of Marine Science, University of Dar es Salaam, Mizingani Rd., PO Box 668, Zanzibar \\ 3 Stockholm Resilience Centre Stockholm University, Kräftriket 2B, 10691 Stockholm, Sweden
}

Received 14 July 2010; Accepted 29 November 2010

\begin{abstract}
This study assessed the Zanzibar sea cucumber fishery using a multidisciplinary approach. Data was collected by (i) interviewing various groups of actors in the fishery and reviewing management documentation and legislation, (ii) by monitoring catches and (iii) through a visual census of coastal sea cucumber populations in areas open and closed to fishing. The fishery showed clear signs of being unsustainable with high fishing effort, and weak formal and informal management institutions. The fishery operation was characterised by an intricate cross-scale structure with both fishers and sea cucumber products being transported across national borders. The visual census of commercial sea cucumber stocks at three sites open to fishing around Zanzibar showed low densities across the range of sea cucumber value groups including low value species. Furthermore, the diversity of commercial sea cucumber species was lower in fished reefs than on a protected reef. The poor status of the sea cucumber populations was confirmed by the perception of an overfished resource by the interviewed actors active in the fishery. This was also depicted by the paucity of high value species, and high representation of low value and newly commercialised species in fishers catch. We conclude that the current state of Zanzibar's sea cucumber populations is compromising the fisheries self-replenishment and existence and that the fishery is in urgent need of a complete management reform.
\end{abstract}

Key words: Bêche-de-mer / Fisheries / Overfishing / Holothurians / Echinoderms / Trepang / Western Indian Ocean

\section{Introduction}

During the past decades it has become apparent that many stocks of fisheries resources around the world have collapsed as a result of overfishing (e.g. Pauly et al. 2002). Especially highly commercial species have suffered, and harvest of less commercially valuable species have followed in their place (Pauly et al. 1998). The reasons for these collapses are complex (Cochrane 1999), and include for instance institutional weakness (Stephenson and Lane 1995), complex governance issues (Jentoft and Chuenpadgee 2009), narrow approaches focussing on regulations and ignoring cultural and normative factors (de la Torre-Castro and Lindström 2010), and ecological uncertainty (Ludwig et al. 1993). The lack of basic knowledge on ecological life histories of many invertebrates, together with sessility or low motility, makes them particularly vulnerable to overfishing (Perry et al. 1999). Belonging to this category of resources are Aspidochirotid sea cucumbers, which are harvested to produce the commercial high-valued beche-de-mer (also known as trepang) - the dried body wall of the sea cucumber traded and consumed

\footnotetext{
${ }^{a}$ Corresponding author: hampus@ecology.su.se
}

in Asia (Conand 1990; Conand and Byrne 1994). Predominantly Chinese communities cherish this item as a delicacy, health tonic and aphrodisiac, and its status as a trade commodity in the central Indo-Pacific was well established during the $18^{\text {th }}$ century (MacKnight 1976). The fishery and trade has since then spread and intensified and today beche-de-mer is a common export commodity from many Western Indian Ocean countries (Conand and Muthiga 2007; Conand 2008; Ochiewo et al. 2010), as well as in many other tropical and developing regions (Toral-Granda et al. 2008; Purcell 2010a).

In Zanzibar (Tanzania, East Africa), local people do not recognise sea cucumbers as food items, instead the fishery for sea cucumbers was introduced for export of beche-de-mer and is a source of income for the actors involved (Jiddawi and Öhman 2002). The fishery also provides national revenue from export taxation. It is difficult to state when the sea cucumber fishery in Zanzibar commenced. Intensification of Asian markets demand in Africa took place at the beginning of the second millennium (Sheriff 1987) and records of marine products commerce have been reported since the $18^{\text {th }}$ century, along with the establishment of small Chinese communities (Gilbert 2004). According to the interviews in this study, the contemporary exploitation of the product gained momentum when 
the Chinese immigrants pushed the fishery in Unguja island (the largest island in the island group commonly referred to as Zanzibar) in the late 1960s for own consumption and export. The fishery and its market have since then developed and the sea cucumber fishery in Zanzibar has been documented as high valued and under increasingly high fishing pressure (Coleson and Jiddawi 1996; Jiddawi and Öhman 2002). However, no systematic studies of sea cucumber stocks or ecology have been performed.

Zanzibar's coastal communities rely heavily on the marine environment for subsistence and income (Jiddawi and Öhman 2002; de la Torre-Castro 2006), with about $85 \%$ of the coastal population living on less than one US dollar per day (Ruitenbeek et al. 2005; de la Torre-Castro 2006). Despite an increasing research attention on the marine resources in Zanzibar many fish stocks that provide elements of subsistence are declining (Jiddawi and Öhman 2002; de la TorreCastro and Rönnbäck 2004). The Department of Fisheries and Marine Resources (DFMR) is the "government institution, which is directly responsible for day-to-day fisheries management in Zanzibar" (The Fisheries Act 2005). Even though formal institutional structures are in place, and perceived as robust and well designed (Ruitenbeek et al. 2005), performance of formal management in the coastal fishery in Zanzibar is strongly influenced by normative and coastal institutions (de la Torre-Castro \& Lindström 2010), and the general poverty situation (de la Torre-Castro 2006).

Aspidochirotid sea cucumbers are generally detrivorous and provide important ecosystem functions through bioturbating behaviour and by regenerating nutrients through feeding (Uthicke and Klumpp 1998; Uthicke 1999). Therefore overfishing of sea cucumbers likely reduces ecosystem productivity (Wolkenhauer et al. 2010). Artisanal fishing can deplete stocks already after a handful of years, and recovery is generally slow and dependant on many factors for which there is limited information (Friedman et al. 2010). The many examples of sea cucumber overfishing (Toral-Granda et al. 2008; Purcell 2010a), together with prevailing Allee effects (Levitan and Petersen 1995; Bell et al. 2008), major knowledge gaps in ecology (Conand 1990; Uthicke et al. 2004a), and unpredictable recruitment (Uthicke et al. 2009), suggest that a precautionary management approach is appropriate for this fishery. However, this is often not the practice (Purcell 2010a), and for example, depicted in mainland Tanzania where authorities have placed a moratorium on exports of sea cucumbers due to overfishing (Mgaya and Mbaga 2007). Fisheries closures due to overfishing, or concerns of overfishing, are common (Friedman et al. 2008; Purcell 2010a), and emphasises the high vulnerability to fishing.

In this study we investigated the sea cucumber fishery on Unguja Island in Zanzibar. First, we approached fishing methods, fishers' organisation and formal and informal management by interviewing actors in the fishery. In this part of the study, we also established the livelihood importance of the resource by evaluating the level of dependence on the activity, and the involvement of different actors in the fishery. Second, we performed catch monitoring to assess the species and value distribution in fishers catch. Third, we assessed the status of sea cucumber populations for species with a commercial value using visual census of coverage and density along the seascape, and estimated the effects of the fishery by sampling in a no-fishing protected marine park as well as in fished areas. This fishery lacks baseline data so we analyzed the results by taking into consideration the perceptions among interviewed actors in the fishery.

\section{Methods}

\subsection{Interviews with fishery actors}

Fishing methods and the organization of the fishery were addressed by using semi-structured interviews. The interviews were conducted from October 19 to December 31, 2007 in eight different sites (Mkokotoni, Mazizini, Fumba, Unguja Ukuu, Nungwi, Mtende, Uroa and Chwaka villages) (Fig. 1). The sites were selected trying to cover most parts of the island and based on information of where the fishery was active.

All groups of actors involved in the local fishery were interviewed: fishers $(n=72)$, middlemen $(n=15)$ and traders $(n=5)$ as well as senior management officials $(n=8)$ and local monitoring agents $(n=15)$ (referred to as beach recorders or "Bwana dikos" in Kiswahili, see de la Torre-Castro 2006). All the large export traders located in Zanzibar urban area and most of the local market middlemen were interviewed. Fishers were selected randomly while living in the villages.

The interviews were conducted in Swahili (with the assistance of a translator) but some management officials and export traders were interviewed in English. All interviews were semi-structured (Kvale 1996; Denscombe 1998) and provided material for qualitative and quantitative analysis. The answers for the quantitative analysis were categorised into answer groups (e.g. "positive", "negative" or "unsure") to perform further analysis. In addition to the interviews, informal discussions with fishers and middlemen were also conducted. These were, along with observations, used in particular to approach the clandestine diving activity in the fishery.

The interviews focused on the way the fishery is operated, management (i.e. both formal institutions such as formulated laws and regulations sanctioned by government agencies or authorities, and informal institutions such as community level practices and codes of conduct not formally established as laws but that may provide a sustainability function for the fishery), and social-ecological aspects of the fishery following de la Torre-Castro et al. (2007). In particular, the aim with the interviews was to provide understanding of the fishery structure and chain of actors involved, the fishing methods and scales and areas of operation, management perception and awareness of the legislation, perception of fishery changes over time and finally the reasons to be a sea cucumber fisher and possible livelihood alternatives. The interview form is available upon request.

Parallel to the interviews literature and policy documentation were collected from the Department of Fisheries and Marine Resources (DFMR) and the Department of Environment, and analysed to identify current legislation and management of the sea cucumber fishery. 


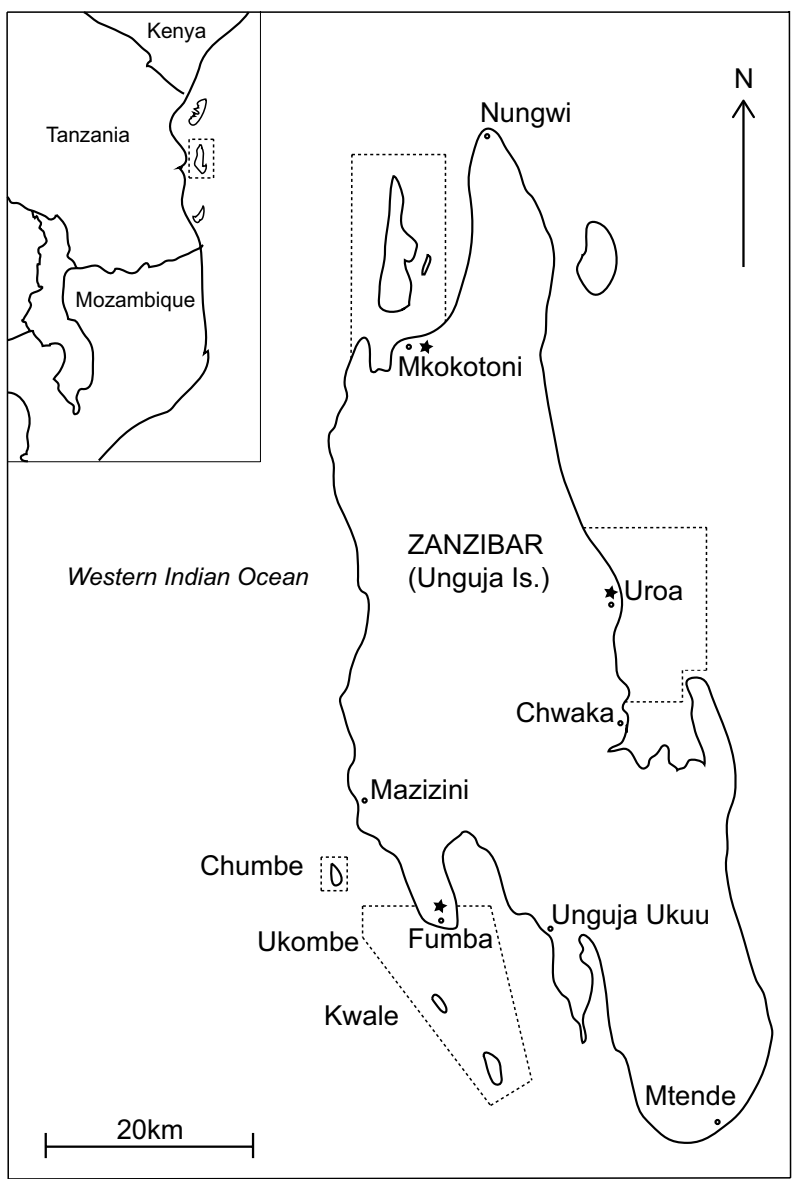

Fig. 1. Study area Unguja Island (Zanzibar, Tanzania) $6^{\circ} 8^{\prime} 0^{\prime \prime} \mathrm{S}$, $39^{\circ} 19^{\prime} 0^{\prime \prime} \mathrm{E}$. Interviews were conducted in villages indicated by a filled circle. Catch assessment and visual census of stock were carried out in villages marked out with a star $\star$. The areas outlined with dotted lines adjacent to the villages marked with a star indicate where visual census of sea cucumber populations were performed. Note that Chumbe is not included in the Fumba area but it was used for the comparison of species richness with Ukombe and Kwale reefs that were sampled inside the Fumba area.

\subsection{Catch monitoring}

Daily catch data was collected in the landing locations in three selected sites (Fumba, Mkokotoni and Uroa villages) (Fig. 1) between June 23 and August 23, 2009 during approximately two weeks in each site. Species, quantity and fishing effort (number of fishers and time spent fishing) was recorded. On occasions, catch and effort data was also collected cooperating with the trade middleman (person buying local catches for further distribution and/or processing) as a key-informant. The species value was recorded as the purchasing price offered by the middlemen to fishers at point of landing. Length measurements of Holothuria scabra were collected from all individuals found in the catch at the site Fumba. This species was used for analysis as it was regularly observed in catch in this location and its body wall is relatively rigid reducing measurement variability (Purcell et al. 2009).

\subsection{Visual census of commercial sea cucumber stocks}

The condition of the commercial sea cucumber stock was investigated using a visual census of sea cucumber populations during June 23, to August 23, 2009 in the coastal areas around three villages i.e. Mkokotoni, Fumba, and Uroa (Fig. 1). These specific sites were chosen because they have an active fishery and the geographic location provides fishery information from different sites around the island. Stocks where sampled using two techniques at different scales: a broad-scale assessment using manta tows, and a fine-scale assessment using swimming (or walking) line transects. Manta tows were performed following methods outlined in English et al. (2003) and covered $300 \times 2 \mathrm{~m}$ (measured using a handheld GPS) at depths between $0.5-8 \mathrm{~m}$, targeting reef and lagoon areas. Manta tows provide a suitable spatial scale to sample at when assessing commercial sea cucumber populations (Uthicke and Benzie 2000; Purcell et al. 2009), but may under-estimate some species due to their ecology (e.g. diurnal behaviour) (Shiell and Knott 2008). Stocks were also surveyed using line transects covering $40 \times 1 \mathrm{~m}$ by swimming or walking in shallow areas. Transects specifically targeted reef or soft benthic areas in places where manta tows were not suitable, e.g. shallow reef areas and muddy lagoons. The smaller sample area allowed the surveyor to turnover rocks and dig in sand to find cryptic or burying species (Purcell 2010b).

Sea cucumber populations were also assessed in the reef areas of Chumbe Coral Park that is a private-run marine park protected from fishing since 1994 (Riedmiller 1998). Chumbe provides a reference site for comparison of commercial sea cucumber assemblage to the nearby reefs Ukombe and Kwale that are open to fishing, but under locally developed regulation since 1994 (e.g. restriction of fishing camps to exclude outsiders, local monitoring programmes) (Ngaga et al. 1999). These three reefs are located approximately $5 \mathrm{~km}$ apart, and on similar SW aspect. Each site was sampled at the same effort $(n=12)$ with the manta tow method described above. Species diversity between the three reefs was assessed using a comparison of a cumulative unique species count, and ShannonWiener diversity index $\left(H^{\prime}\right)$ (Peet 1974). The order of transects for the cumulative species count for each reef was simulated with permutations ( $n=20)$ using R 2.10.0 to calculate a mean cumulative number of species per sample size and reef.

\section{Results}

\subsection{The fishery operation}

The general structure of the domestic fishery trade system followed a "Fisher - Middleman - Trader" chain, similar to that described by Conand (1997), and in nearby Kenya (Ochiewo et al. 2010).

Fishing was conducted using three methods: gleaning, breath hold diving and scuba diving. We estimate that there were at least 800 fishers regularly participating in the fishery. Gleaning was generally undertaken by women collecting benthic fauna in intertidal seagrass areas, and the latter two divingmethods were generally undertaken by men in deeper areas both on soft bottoms and in reef areas (Table 1). The fishers 
Table 1. Outline of the sea cucumber fisher types in Zanzibar.

\begin{tabular}{|c|c|c|c|}
\hline Type & Gleaning & Breath hold diving & Scuba diving \\
\hline Range & Intertidal & Intertidal - Subtidal & Subtidal \\
\hline Depth & $<1 \mathrm{~m}$ & $1-10 m$ & $10-50 m$ \\
\hline Target area & Near shore shallow areas & $\begin{array}{l}\text { Local fishing grounds (but may be } \\
\text { more mobile) }\end{array}$ & $\begin{array}{l}\text { Mobile, Zanzibar wide, } \\
\text { Mafia, Pemba, mainland } \\
\text { Tanzania and other } \\
\text { countries of WIO }\end{array}$ \\
\hline Equipment & $\begin{array}{l}\text { Buckets, baskets, bags, } \\
\text { to collect catch }\end{array}$ & $\begin{array}{l}\text { Mask, fins, mesh bag to collect } \\
\text { catch, drag buoy, often use boat } \\
\text { and sometimes speargun to catch } \\
\text { octopus and fin fish }\end{array}$ & $\begin{array}{l}\text { Boat (engine), rustic gear } \\
\text { (single regulator, no bcd, } \\
\text { wetsuit is rare), mesh bag } \\
\text { to collect catch }\end{array}$ \\
\hline Representation & Many & Fewer & $\begin{array}{l}\text { Few (concentrated to a } \\
\text { few villages/sites) }\end{array}$ \\
\hline Demography & $\begin{array}{l}\text { Mostly women, but men } \\
\text { and children too }\end{array}$ & Men & Young men \\
\hline
\end{tabular}

Table 2. Recorded economic value range per individual at point of landing for species and groups of species (local name) in Zanzibar 2009.

\begin{tabular}{llll}
\hline Species group & Species & Value range (TZS) & Value category \\
\hline Pauni & Holothuria nobilis, H. fuscogilva (cf), H. "pentard" * & $300-20000$ & High \\
Spinyo baba & Theleonota ananas & $4000-8000$ & High \\
Barangu & Holothuria lessoni & $500-7000$ & High \\
Myeupe & Holothuria scabra & $150-4000$ & High \\
Nanasi & Holothuria spinifera & $1000-2000$ & Medium \\
Spinyo mama & Theleonota anax & $1000-2000$ & Medium \\
Tairi & Stichopus herrmanni, Stichopus sp. ** & $100-1500$ & Medium \\
Kijini & Actinopyga miliaris & 1500 & Medium \\
Dole & Bohadschia atra, B. vitiensis** & $150-1000$ & Medium \\
Barangu mwamba & Holothuria fuscopunctata & Medium \\
Sankude & Stichopus sp. ${ }^{* *}$ & 500 & Low \\
Tambi & Bohadschia maculisparsa, B. subrubra** & $200-300$ & Low \\
Mbura & Actinopyga mauritiana, A. echinites, A. lecanora & $150-200$ & Low \\
Kichupa & Holothuria atra, H. leucospilota, H. coluber & $100-200$ & Low \\
Shirimeni & Holothuria isuga & $20-150$ & Low \\
Disera & Actinopyga capillata & $50-200$ & Low \\
\hline
\end{tabular}

* See Uthicke et al. 2004b for phylogeny of teatfish complex and Conand 2008 with regard to H. "pentard". ** The Stichopus varieties are part of a cryptic species complex that is under cur rent taxonomic review (Byrne et al. 2010). ${ }^{\star \star *}$ The Bohadschia varieties ae also part of a cryptic species complex under taxonomic review, identification is difficult and scientific names may change (personal communication Maria By rne). There is some confusion regarding the Dole and Tambi groups but p rocessors report that Dole has a higher recovery rate to marketable product. 1 USD $=1355$ TZS, 1 EUR $=1854$ TZS (2010/03/02)

landed the catch either in the village or in designated landing sites for mobile divers. The middleman purchased the catch live from the fishers and generally performed the first stage of processing by boiling and storing the animal in salt before selling it to the exporting traders. These traders performed the final drying stage of the processing to marketable product. A fisher could occasionally be a middleman as well, purchasing catch from other fishers and selling it wet or boiled to traders. There were also examples of traders that purchased wet sea cucumbers directly from fishers, thereby eliminating the middleman role. Middlemen frequently gave credit or equipment to fishers, which create an informal agreement structure important for both actors, i.e. fishers (obtained cash when needed) and middlemen (securing future catch and loyalty in return for credit).

The divers fished at depths down to $50 \mathrm{~m}$ with poor training and worn-out equipment (no buoyancy control device, old regulators, rusting steel tanks were observed). The diving fishers were opportunistic and harvested in areas based on experience and hearsay, both in nearby fishing grounds and in distant waters requiring days at sea. The high mobility of the divers was a recent feature of the fishery as a result of near shore overfishing as indicated in interviews. 


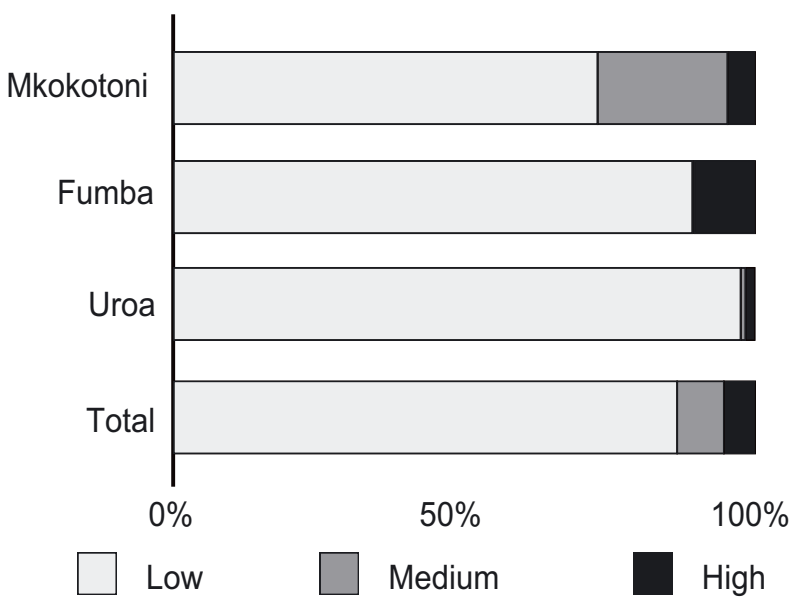

Fig. 2. Catch composition according to commercial value group (low, medium and high) from the areas surrounding the villages presented. See Table 2 for key to which species are included in each value category.

\subsection{Management and perceptions of the fishery}

The sea cucumber fishery was included in the broader "fish" section in The Fisheries Act of 1988 and the revised Fisheries Act of 2005 of Zanzibar, but was not specifically mentioned as a separate fishery. There were no sea cucumber fishing licenses but according to The Zanzibar Constitution 1984 Order, a legal supplement to the Zanzibar Government Gazette, the fishery was managed by a length restriction of $100 \mathrm{~mm}$ for "Holothuriodea". The existence of this formal length restriction was, however, only known to $50 \%$ (four out of eight) of the interviewed DFMR senior management officials, by $7 \%$ (one out of 15) of the interviewed local monitoring agents ("Bwana dikos"), by $13 \%$ (two out of 15) of the middlemen and by $3 \%$ (two out of 72) of the fishers. None of the respondents (management officials, monitoring agents, middlemen or fishers) that were aware of the restriction could account for the specific length. Traders were required to purchase an annual license. There was no restriction on the number of export licenses.

Out of the interviewed fishers, $28 \%$ described an awareness of informal management (i.e. community level arrangements or practices that are not established and passed as formal laws). The interviewees mentioned agreements such as "not allowed to collect during night", "only collect large sea cucumbers", or more general restrictions such as "not allowed to destroy environment", "only fish during NE monsoon", "foreign collectors must pay [to the] village committee", "other villagers not allowed to collect". $20 \%$ of the fishers said that the arrangements were not being followed in conduct. A quarter $(28 \%)$ of the fishers said that they couldn't consider stopping sea cucumber fishing, while ca. $60 \%$ of the interviewed fishers said that they could agree to an occasional or seasonal closure (three months or up to a year).

Almost all of the fishers and middlemen (94\% and 92\% respectively) answered that it was harder to find most species today than when they first engaged in the activity, emphasising a dramatic decline in the status of the resource. In addition, $93 \%$ of the interviewed middlemen wanted access to capital

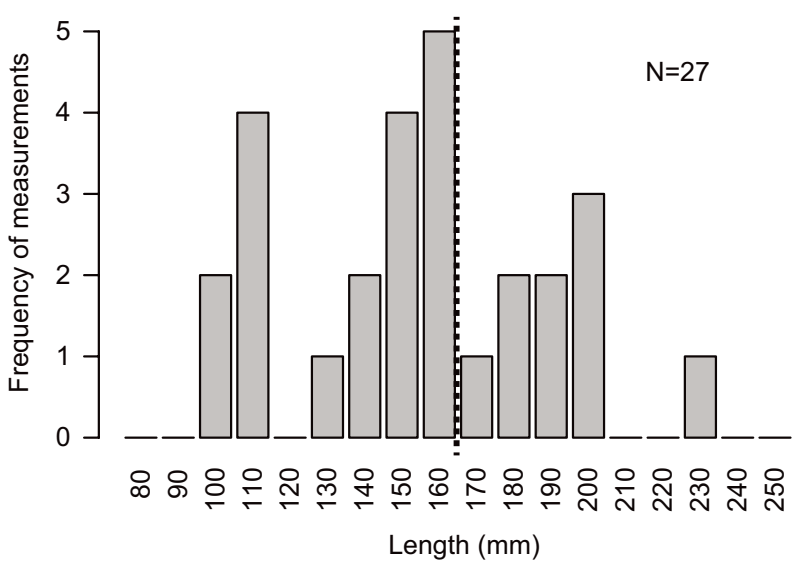

Fig. 3. Length frequency distribution with $10 \mathrm{~mm}$ intervals of Holothuria scabra recorded in fishery catches in the village of Fumba during July 22-30, 2009. The dotted line is the size at sexual maturity (160 mm; e.g. Conand 1993).

to employ fishers or to invest in equipment such as motors, boats, diving gear etc., to rent to fishing teams to increase the effort in the fishery. In a similar manner, $76 \%$ of the fishers said that they want equipment such as motors, boats, diving gear, protective shoes etc. to improve their activity.

When approached with the question of what the fisher would do if the opportunity to fish sea cucumbers was lost, nearly one quarter $(24 \%)$ indicated that they would struggle to find another source of income. Out of the remaining $76 \%$, $55 \%$ stated that the alternative was another type of marine resource extraction (finfish, octopus, lobster or seaweed farming), $19 \%$ mentioned land based activities such as farming or firewood collection, $23 \%$ mentioned small businesses and $4 \%$ mentioned education as an alternative.

\subsection{Catch assessment}

A total of 2030 animals caught by 347 fishers were counted in catch. The value range of recorded species groups is summarised in Table 2. The catch per unit effort (CPUE) was ca 1.1 individuals $\mathrm{h}^{-1}$, estimated from the mean reported time spent fishing by interviewed fishers $(5.3 \mathrm{~h})$. The majority of the catch consisted of low value species (Fig. 2), with local names species groups "Kichupa" (Holothuria atra, H. leucospilota and H. coluber), "Mbura" (Actinopyga lecanora, A. mauritiana and A. echinites) and "Sankude" (Stichopus sp.) being the most common. Length frequency distribution of caught Holothuria scabra showed that the majority of the measured animals are harvested before its estimated length of maturity (160 mm; Conand 1993) (Fig. 3).

\subsection{Commercial sea cucumber stock status}

The visual census of sea cucumber stocks covered a total area of 16 ha of benthos using 269 manta tows (including Chumbe) and 258 line transects. Sea cucumbers of any commercial value (low, medium or high) were only found in approximately $45 \%$ of the manta tow replicates and about $15 \%$ of 
a) Manta tows

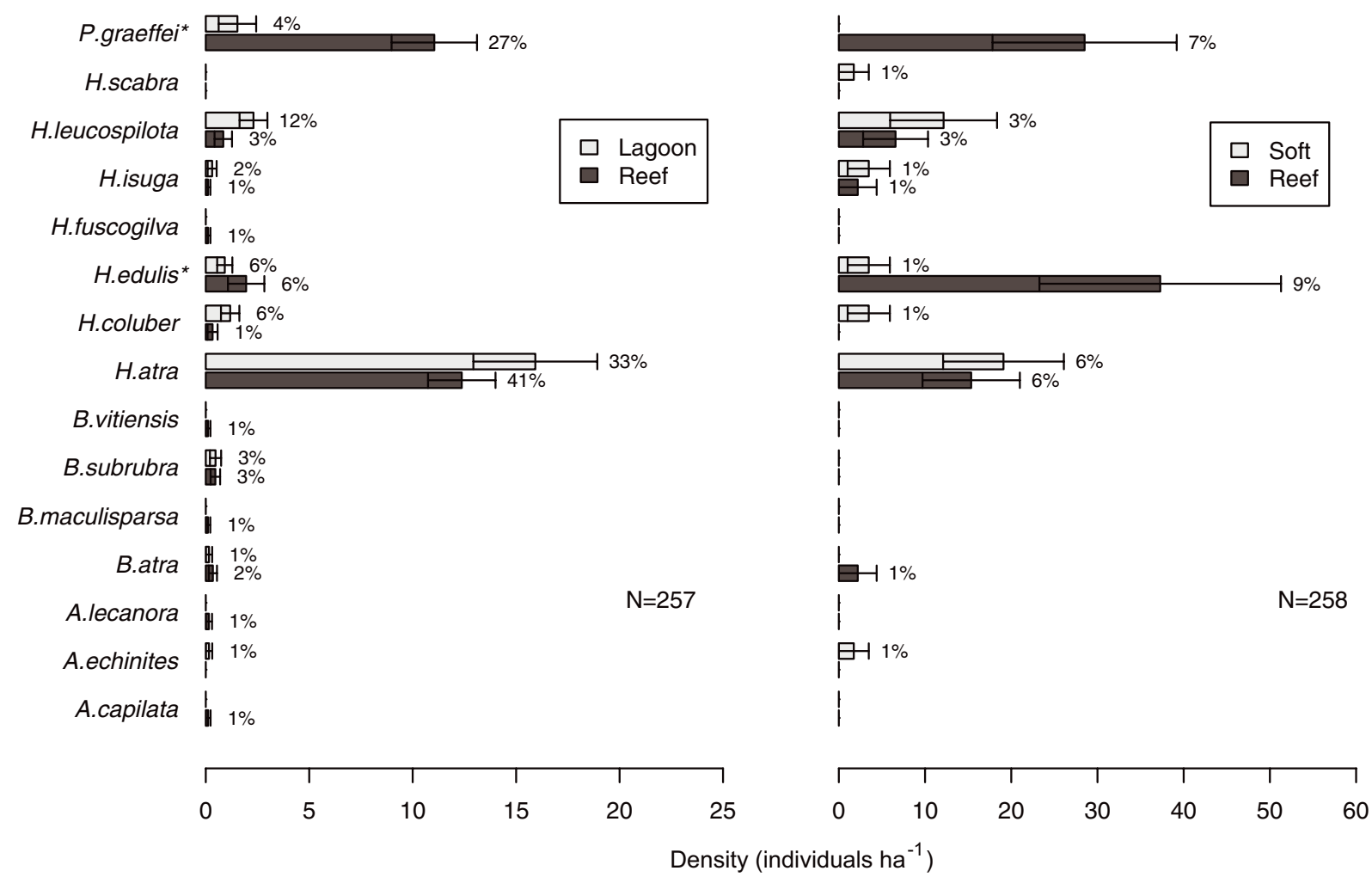

Fig. 4. Mean density of no. individuals $\mathrm{ha}^{-1}$ in the three surveyed sites in Zanzibar. Tails are \pm SE. Percent numbers above bars represent occurrence in the total amount of transects for that environment and method. a) $300 \mathrm{~m} \times 2 \mathrm{~m}$ Manta tows targeting reef environments $(n=148)$ and lagoon environments $(n=109)$. b) $40 \mathrm{~m} \times 1 \mathrm{~m}$ Transects targeting reef benthos $(n=114)$ and soft benthos $(n=144)$. $* P$. graeffei and $H$. edulis are not harvested in Zanzibar.

the line transects in areas open to fishing. The survey revealed a striking paucity of high value species and very low coverage and densities of medium value species using manta tow method and line transect (Fig. 4a,b). The low value species $H$. atra was the most commonly recorded species. Pearsonathuria graeffei was also regularly found in reef environments. This species is not fished in Zanzibar but is commercial in other places (Rasolofonirina et al. 2004; Kinch et al. 2008a). Only one animal of the high value species Holothuria scabra was found in transects targeting suitable soft benthos areas yielding a very low occurrence and density. No other species of medium or high value were recorded using this method. Results from the manta tow method were pooled into value groups (low, medium and high; Table 2) for each site and reveals the striking scarcity of commercial medium and high value species groups in village fishing grounds, both in terms of occurrence and recorded density (Fig. 5).

The Shannon-Wiener diversity index $\left(H^{\prime}\right)$ was found to be higher in the protected site Chumbe $\left(H^{\prime}=1.73\right)$ than in the fished reefs Ukombe $\left(H^{\prime}=1.04\right)$ and Kwale $\left(H^{\prime}=0.50\right)$. On Ukombe reef some individuals of $H$. atra were recorded, which increases this reef $H^{\prime}$-value as the index includes an abundance measure. The cumulative species count shows nearing asymptotes for Ukombe and Kwale, whereas Chumbe has a steeper slope and an increasing trend at the same sampling effort (Fig. 6), which highlights a less diverse commercial sea cucumber assemblage in the reefs open to fishing. In addition, Chumbe reef was the only site where the high value species black teatfish, $H$. nobilis (1.2 individuals $\left.\mathrm{ha}^{-1}\right)$, and the medium value species $S$. herrmanni $\left(9\right.$ individuals $\mathrm{ha}^{-1}$ ) and $T$. anax (2.5 individuals ha ${ }^{-1}$ ) were recorded in this study, along with a ten times higher density for the medium value species $B$. atra ( 5 individuals $\mathrm{ha}^{-1}$ ) compared to the sampled areas open to fishing. This emphasises the positive protection effect from fishing on the commercial sea cucumber assemblage in Chumbe despite its small size $(300 \mathrm{~m} \times 1100 \mathrm{~m})$.

\section{Discussion}

\subsection{The fishery operation and management}

The fishery includes men, women and children and operates using different modes of collection and effort. For example, women collect sea cucumbers in intertidal areas during the low tide while the highly mobile (men) breath hold and scuba divers target offshore areas, villages with no resident divers, and even waters in other countries in the region with high effort. None of the harvesting activities are monitored or controlled. The mobile divers and the reported connections within the Zanzibar commerce structure from other 

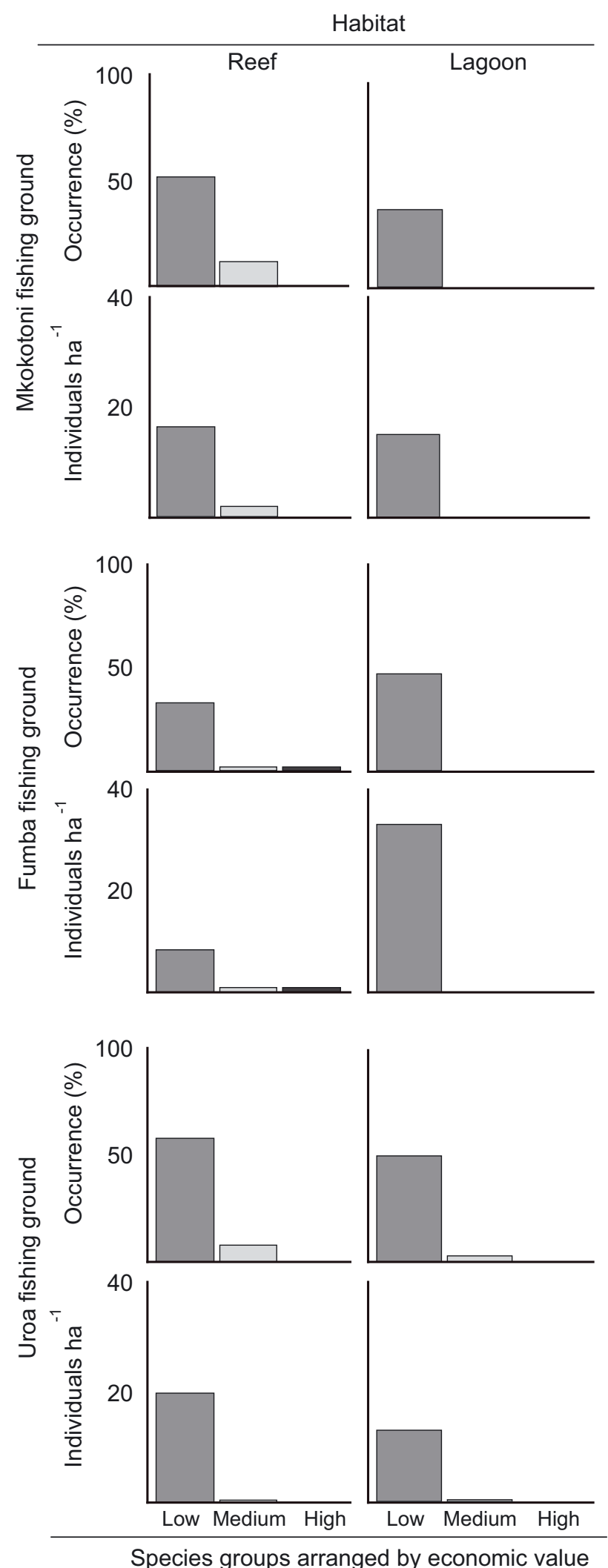

Fig. 5. Pooled occurrences (\% of records in transects) and densities (individuals $\mathrm{ha}^{-1}$ ) of high, medium and low commercial value sea cucumber species in reef and lagoon environments using manta tow assessment method. For key to which species are included in each value category please refer to Table 2 .

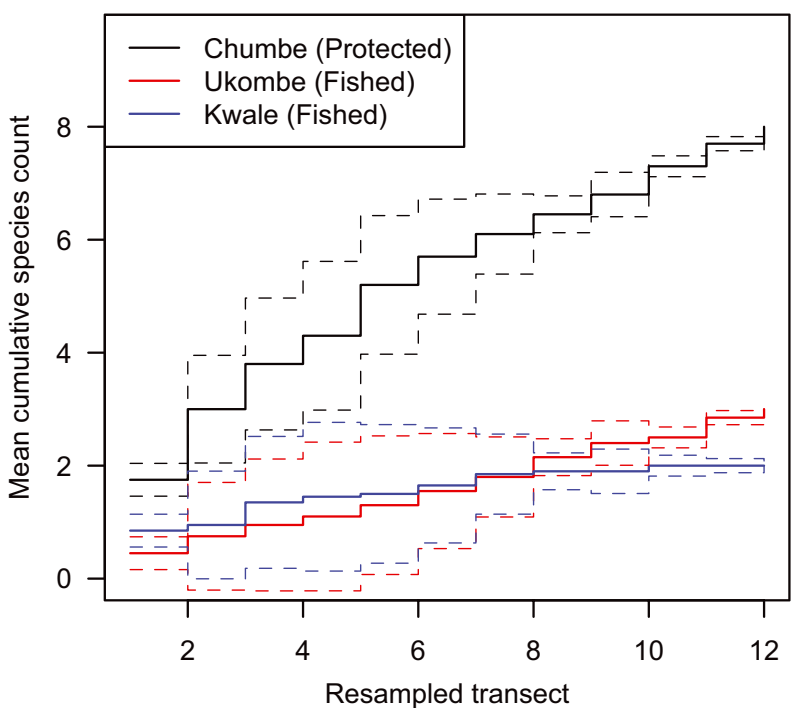

Fig. 6. Cumulative commercial sea cucumber (Holothuroidea: Aspidochirotida) species richness for the protected Chumbe, and fished Ukombe and Kwale reefs (see location in Fig. 1) sampled with manta tows $(n=12)$. The order of transects was simulated with permutations $(n=20)$. Plotted data is the mean increment increase in species per transect for simulated combinations of sampled transects. Dotted lines are 95\% confidence interval. The slope and asymptotes of the cumulative curves illustrate that Chumbe reef, which is protected from fishing, has higher diversity in commercial sea cucumbers.

areas in the region suggest an intricate cross-scale and crossborder structure. During the study smuggled batches of sea cucumbers from Tanzania mainland were observed at trader's facilities (mainly medium and high value species $H$. scabra, $S$. herrmanni, T. ananas, $T$. anax, and the three teatfish varieties), which indicates that Zanzibar could be a regional exit point for legally and illegally fished sea cucumbers. Zanzibar reportedly also receives migratory fishers, middlemen and trading agents from mainland after the closure there. Reportedly the migrating fishers set up camps to harvest in areas around Zanzibar. The scales (e.g. Cash et al. 2006) of sequential exploitation in the fishery include both spatial (geographical area and depth), temporal (day and night, throughout the year) and species range (targeting an array of species). Reported problems with the influx of fishers, other than competition for resources, included environmental degradation in camping areas where firewood is collected to prepare the sea cucumber products and for cooking.

The current formal management is insufficient to control the fishery, both in terms of lack of regulation and lack of implementation. The weak formal management capacity is illustrated for example by the paucity of formation of rules and laws. In addition, our findings illustrate that there are some existing informal arrangements in the sea cucumber fishery that can support management. However, few of the fishers are aware of them and they are not customary as norms of behaviour, hence, they provide a weak instrument for sustainability. To design management and institutional structure to control the fishery the structures and scales of the fishery operation are important to identify (Lee 1993; Holling 2001; Folke et al. 2007). Given the regional trading structures, 
bridging institutional structures, and coordinated management between the involved areas and countries is needed. Regional approaches towards management of invertebrate exports are being explored and encouraged in the South Pacific to address similar cross-scale reasons (Friedman and Chapman 2008). Additionally, effort to control the sea cucumber trade at a "higher" policy level is pursued via the possible trade protection under the Convention on International Trade in Endangered Species Wild Fauna and Flora (CITES) (Bruckner et al. 2003). A major constraint for CITES listing is that the taxonomy for many commercial sea cucumbers has not been resolved (Massin et al. 2009), the slow formation of regulation in relation to the rapid progress of fishing (Berkes et al. 2006), and the apparent lack of monitoring and enforcement at the local fishery level as illustrated in this study.

Management based on an ecosystems approach is prescribed for sea cucumber fisheries (Purcell 2010a), as it recognises humans and society as integral in the fishery system, thereby capturing the complexity of the sea cucumber ecology and beche-de-mer trade under its framework. Interviewed fishers seemed positive to shorter seasonal closures of the fishery in order to increase catches. However, the efficiency of maintaining healthy stocks through shorter closures is questionable as a management measure (Purcell 2010a). The role of the international trader is to facilitate the transport of the animal from the ecosystems to the recipient markets, while making a profit. Through this role the traders perform a key function in the trade system linking the world market to the local fishery system and the ecosystem. In Zanzibar, the traders are not under control today but their linking function is indeed important to acknowledge in management (Crona et al. 2010). The manager's responses in discussions showed awareness of a degraded and declining fishery. The fact that decisions are not being made, or that those that are made are not being communicated or enforced, may be due to a mismatch between the normative, cultural and regulative institutions (de la Torre-Castro and Lindström 2010). The environmental policy for Zanzibar (1997) concurs with this finding and states that a constraint in performance of management of the coastal zone is the "lack of comprehensive institutional arrangement that provides mechanism for interagency intersectoral cooperation and collaboration". Management officials also mention lack of funds and resources as a determinant in conducting socio-economic or stock assessment and developing management strategies (jointly with communities or otherwise).

\subsection{The fishery as a livelihood}

Fishers were paid for their catch at landing sites and the middlemen or traders then processed the catch into products, thereby earning the added value in the market. That traders perform processing to final product is common and reduces the potential for fishers to add value of their catch (Friedman et al. 2008). Price varied markedly for price at point of landing with observations of $85-94 \%$ price differential for similar catch in different locations (Table 2). Hence, local fishers (mainly women gleaners) are exploited for profits and do not get a reasonable market price for their catch. This situation is not unique to the Zanzibar sea cucumber fishery, but has been observed in Asia (Choo 2008) and Kenya (Ochiewo et al. 2010), as well as in other marine resources trade structures like commercial seaweed farming (Brycesson 2002). Most importantly, such inequalities hinder poverty reduction (Walmsley et al. 2006), and reduce the sustainability of the fishery even further. This issue is worsened by the reliance on sea cucumbers among those involved in the fishery, with about one quarter of the fishers arguing that they would struggle to find alternatives at all. This scenario is similar to that noted in nearby Kenya (Ochiewo et al. 2010). The interviewed fishers mention other marine resources, agriculture and firewood collection as alternatives to harvesting sea cucumbers, illustrating that the activity to fish sea cucumbers is part of a societal conduct of natural resource use rooted in a society with few market-based alternatives and poverty (Anderson and Ngazi 1998; de la Torre-Castro 2006). The narrow range, and deteriorated status, of alternativesamong the fishers in Zanzibar, suggests that it will be difficult to change conduct or implement restrictions to allow recovery of the fishery and that it will affect communities ability to support themselves.

\subsection{Catch and resource status}

The low awareness of the length restriction $(100 \mathrm{~mm})$ among all actors in the fishery is probably one of the clearest examples of the poor performance of current management. However, the matter is worsened even further as the length restriction is smaller than the known body size of sexual maturity of any commercial sea cucumber species (Conand 1993). The results from the catch monitoring manifests that sea cucumbers smaller than estimated length at sexual maturity, and legal length, is indeed being harvested. The lack of sustainability is also depicted by the ambition among fishers and middlemen to increase effort despite the awareness that the fishery is declining.

Historical CPUE values are not available for trend analysis of catches. Instead, this study focussed on perceptions of fishery trends among fishers, rather than asking them for historical catches in numbers, which is laden with uncertainty. The modest CPUE recorded ( 1.1 animals $\mathrm{h}^{-1}$ ) illustrates the reported dramatic decrease in catches by almost all of the interviewed fishers (94\%). Catches were generally handled negligent and left on sand or in sun for longer periods, degrading the body walls and reducing the quality of the product. Simple measures such as improving handling of catch and processing (through training) can provide added value to the catch. In particular Stichopus varieties suffer from "degenerating" body wall tissue and improper handling can reduce the value of the product by 20-30\% (Ram et al. 2010). The Stichopus varieties noted in catch are part of a cryptic species complex (Byrne et al. 2010). Holothuria isuga was frequently recorded as a low value species in the fishery. This species has previously been noted in New Caledonia (Purcell et al. 2009) and on One Tree Reef in Australia (H. Eriksson pers. obs.), however it is not encountered as a commercial species in the main taxonomic surveys in the region (as compiled by Conand and Muthiga 2007). In addition, the high value teatfish variety Holothuria sp. "pentard" (e.g. Conand 2008), that 
Table 3. Fishery status summary following indicators in Friedman et al. (2008).

\begin{tabular}{|c|c|c|}
\hline Indicator & Results & Conclusions \\
\hline $\begin{array}{l}\text { Presence of breeding } \\
\text { groups }\end{array}$ & $\begin{array}{l}\text { Low densities and coverage levels of coastal commercial sea cucumber stock } \\
\text { with no aggregates of medium or high value species recorded. }\end{array}$ & $\begin{array}{l}\text { Stock depletion, replenishment of stock } \\
\text { constrained * }\end{array}$ \\
\hline Fishing gear used & $\begin{array}{l}\text { Both "traditional" hand collection at low tide by women and children and } \\
\text { breath hold and scuba diving by men in organised fishing teams. The diving } \\
\text { teams are highly mobile and travel far from nearshore overexploited areas. } \\
\text { High effort required to find commercial sea cucumbers of any value. }\end{array}$ & $\begin{array}{l}\text { Diving teams illustrate nearshore stock } \\
\text { depletion, high effort, lack of regulation } \\
\text { leading to overexploitation }\end{array}$ \\
\hline $\begin{array}{l}\text { Sea cucumber } \\
\text { abundance }\end{array}$ & Low abundance and coverage levels of commercial sea cucumbers recorded. & $\begin{array}{l}\text { Stock depletion, replenishment of stock } \\
\text { constrained, high effort }\end{array}$ \\
\hline $\begin{array}{l}\text { Ratio of species } \\
\text { abundance }\end{array}$ & $\begin{array}{l}\text { Predominantly low value or newly commercialised species, with absence of } \\
\text { high value species and very low abundance of medium value species, in both } \\
\text { catch and water. }\end{array}$ & $\begin{array}{l}\text { Stock depletion, unsustainable } \\
\text { development of the fishery, high effort }\end{array}$ \\
\hline $\begin{array}{l}\text { Size of sea } \\
\text { cucumbers }\end{array}$ & $\begin{array}{l}\text { The majority of catch is often smaller than estimated size at sexual maturity. In } \\
\text { addition, the length restriction placed on the fishery is ecologically irrelevant } \\
\text { and not followed in conduct. }\end{array}$ & $\begin{array}{l}\text { Stock depletion, reduced "per-piece" } \\
\text { earnings for fishers, replenishment of } \\
\text { stock constrained }\end{array}$ \\
\hline Profit to fishers & $\begin{array}{l}\text { Fishers are exploited for profits not getting a reasonable earning of their } \\
\text { catch. A woman in Fumba receives ca } 10 \% \text { of what a man in Mkokotoni gets } \\
\text { for similar catch. }\end{array}$ & $\begin{array}{l}\text { The resource is not benefitting fishers to } \\
\text { its full potential, market works arbitrarily } \\
\text { with functional anomalies }\end{array}$ \\
\hline
\end{tabular}

*Arguably breeding success may occur for some species in the protected Chumbe Coral Park, however, such "spillover" effects into the fished areas are unknown.

has not yet been described as a species, and the recently described Actinopyga capillata (Rowe and Massin 2006), were also recorded in catch, emphasising that the fishery is targeting species not yet (or recently) described to science. Phylogenetic work is needed to resolve the nomenclature of the species found in the catch in Zanzibar.

The degraded state of the resource due to the fishery is partly illustrated by the paucity of high value species and low densities of medium value species, as well as by the higher diversity of commercial sea cucumbers in the protected Chumbe site than in the fished sites Ukombe and Kwale. Here numerous fishers were observed daily, whereas at Chumbe local rangers patrolled the area (employed by the Chumbe Coral Park administration), and no fishers were present. The additional species found in Chumbe were generally of a higher commercial value. The result of a reduced diversity is in line with studies using Chumbe as an example in addressing macro benthos assemblage differences between protected and open areas (McClanahan et al. 1999; McClanahan and Arthur 2001).

The ability of sea cucumber populations to self-replenish is greatly compromised in reduced densities and may lead to population demise (Bell et al. 2008). Indeed, recovery may take decades despite protection (Uthicke et al. 2004a), which should promote precautious conduct and management (Perry et al. 1999; Friedman et al. 2008). The low densities and coverage levels of commercial species found in this study indicates that few shallow water spawning aggregates remain intact around the coast of Zanzibar today and that management reform is urgently needed. Unfortunately, the knowledge gap in ecology prevents reliable predictions of the future status of this fishery (Conand 1990; Uthicke et al. 2004a; Uthicke et al. 2009). Further ecological research is required to understand species-specific life history and to assist in fisheries management. For instance, deep-water stocks were due to logistical reasons not assessed in this study.

\subsection{Summarising the need for change}

The Zanzibar sea cucumber fishery has passed all indicators (i.e. presence of breeding groups, fishing gear used, sea cucumber abundance, ratio of species abundance, size of sea cucumbers and profit to fishers as outlined by Friedman et al. 2008) that should, in the presence of adaptive management systems, trigger a change in management involvement (Table 3 ). This is also confirmed by the generally negative perception of the status of the resource and weak management as described by fishers, middlemen, and management officials. Our findings illustrate that the contemporary sea cucumber fishery and trade system in Zanzibar resembles the historic one with a strong international market influence, "Patron-client" structures and reciprocal agreements and roving bandits-style sequential exploitation as outlined by Schwerdtner Máñez and Ferse (2010). We propose that the fishery has reached the current point of depletion because of i) the strong influence by the world market, linked to the ecosystem via the traders, that introduced the fishery and then facilitated development to the current high effort and shift to low value species with depletion of high value species, ii) the fishery is institutionally marginalised lacking both formal and informal regulation and control and iii) the long time that the fishery has been operating in this manner, which in turn has also led to iv) the fishery becoming recognised and established as an important source of income among communities with few alternative livelihood options, and v) the ecology of these organisms making them particularly vulnerable towards fishing.

\section{Conclusion}

It is unlikely that the commercial sea cucumber stock size will increase, or the fishery performance will improve, under the current weak management regime, since it fails to provide dialog or restriction in effort despite an awareness of an 
overexploited fishery. At best the fishery will remain at similar levels as today, because of geographical in-accessibility or embedded complexity in the ecology of some species restricting harvest. Based on the results in this study a sea cucumber fishery management reform is urgently needed for stocks to regain and eventually maintain their potential to contribute to the village economies and functioning of the coastal ecosystems. However, restrictions of effort must be strongly anchored in co-management schemes including resource-users and taking the existing normative and cultural institutions in consideration. Otherwise the likelihood of failure is very high as shown in attempts to regulate other fisheries in Zanzibar (de la Torre-Castro and Lindström 2010). To successfully implement control and enhance sustainability we conclude that management requires a better fit to the geographic scale of the fishery (e.g. regional cooperation) and increased participation by fishery actors to address the elements that structure the fishery today, such as: extensive scales (spatial, temporal and species range), lack of formal and informal regulation and control, market anomalies (black market, unfair prices etc.), dangerous and high effort scuba diving, and unsatisfying processing. All of which need attention to promote sustainability, safety, fairness and performance in the fishery.

Acknowledgements. We thank all actors in the fishery that participated in this study. We are grateful for the work conducted by Caroline Raymond (for interviews and field assistance), Hanna Nilsson (for interviews), Muumin Hamad (for field assistance), Said Shaaban (for field assistance), Lina Nordlund, Frida Lanshammar and the Chumbe Coral Park staff (for facilities and assistance), and James Scandol (for assistance in data analysis). We also thank WIOMSA (in particular Dr Julius Francis), the Institute of Marine Science and the Department of Marine and Fisheries Resources in Zanzibar. For valuable comments that enriched this document we thank Göran Samuelsson, Johan Näslund, Nadja Stadlinger and Nils Kautsky. This research was funded by the MASMA/WIOMSA regional sea cucumber project and by the Swedish International Development Agency (Sida).

\section{References}

Andersson J., Ngazi Z., 1998, Coastal communities production choices, risk diversification and subsistence behaviour, responses in periods of transition. Ambio 27, 686-693.

Bell J.D., Purcell S.W., Nash W.J., 2008, Restoring small-scale fisheries for tropical sea-cucumbers. Ocean Coast. Manage. 51, 589593.

Berkes F., Hughes T.P., Steneck R.S., Wilson J.A., Bellwood D.R., Crona B., Folke C., Gundersson L.H., Leslie H.M., Norberg J., Nyström M., Olsson P., Österblom H., Sheffer M., Worm B., 2006, Globalization, roving bandits, and marine resources. Science 311, 1557-1558.

Bruckner A.W., Johnson K.A., Field J.D., 2003, Conservation strategies for sea cucumbers: Can a CITES Appendix II listing promote sustainable international trade? SPC BDM Inf. Bull. 18, 24-33.

Brycesson I., 2002, Coastal aquaculture developments in Tanzania: sustainable and non-sustainable experiences. Western Indian Ocean J. Mar. Sci. 1, 1-10.

Byrne M., Rowe F., Uthicke S., 2010, Molecular taxonomy, phylogeny and evolution in the family Stichopodidae
(Aspidochirotida: Holothuroidea) based on COI and 16S mitochondrial DNA. Mol. Phylogenet. Evol. 56, 1068-1081.

Cash D.W., Adger W.N., Berkes F., Garden P., Lebel L., Olsson P., Pritchard L., Young O., 2006, Scale and cross-scale dynamics: Governance and information in a multilevel world. Ecol. Soc. 11, 8. http://www.ecologyandsociety.org/vol11/iss2/art8/

Choo P.S., 2008, Population status, fisheries and trade of sea cucumbers in Asia. In Toral-Granda V., Lovatelli A.,. Vasconcellos M. (eds.). Sea cucumbers. A global review of fisheries and trade. FAO Fish. Aquac. Techn. Pap. No. 516, 81-118.

Cochrane K.L., 1999, Complexity in fisheries and limitations in the increasing complexity of fisheries management. ICES J. Mar. Sci. 56, 917-926.

Coleson J., Jiddawi N.S., 1996, The sea cucumbers of Zanzibar. IMS Reports (draft).

Conand C., 1990, the fishery resources of Pacific Island Countries, Part Two: Holothurians. fisheries Techn. Pap. No. 272.2.

Conand C., 1993, Reproductive biology of the holothurians from the major communities of the New Caledonian lagoon. Mar. Biol. $116,439-450$.

Conand C., 1997, Are holothurian fisheries sustainable? In: Lessios H., MacIntyre I.G., 8th Internat. Coral Reef Symp. Panama: Smithsonian Tropical Research Institute, Vol. 2, pp. 2021-2026.

Conand, C., 2008, Population status, fisheries and trade of sea cucumbers in Africa and the Indian Ocean. In: Toral-Granda V., Lovatelli A., Vasconcellos M. (eds.). Sea cucumbers. A global review of fisheries and trade. FAO Fish. Aquac. Techn. Pap. No. 516, 143-193.

Conand, C., Byrne M., 1994, Recent evolution of the world fisheries for sea cucumbers. Mar. Fish. Rev. 55, 1-13.

Conand C., Muthiga N. (eds.) 2007, Commercial sea cucumbers in the Western Indian Ocean. WIOMSA Book Series No 5.

Crona B., Nyström M., Folke C., Jiddawi N., 2010, Middlemen, a critical social-ecological link in coastal communities of Kenya and Zanzibar. Mar. Policy 34, 761-771.

de la Torre-Castro M., Rönnbäck P., 2004, Links between humans and seagrasses - and example from tropical East Africa. Ocean Coast. Manage. 47, 361-387.

de la Torre-Castro M., 2006, Beyond regulations in fisheries management: the dilemmas of the "beach recorders" Bwana Dikos in Zanzibar, Tanzania. Ecol. Soc. 11, 35.

de la Torre-Castro M., Ochiewo J., Mbaga T.K., Pinault M., 2007, A framework for addressing socioeconomic and management aspects of sea cucumber resources in the Western Indian Ocean. SPC BDM Inf. Bull. 25, 22-28.

de la Torre-Castro M., Lindström L., 2010, Fishing institutions: addressing regulative, normative and cultural-cognitive elements to enhance fisheries management. Mar. Policy 34, 77-84.

Denscombe M., 1998, The good research guide for small-scale social research projects, 3rd edition, Mc Graw Hill. Open University Press.

English S., Wilkinson C., Baker V., (eds.) 2003, Survey Manual for Tropical Marine Resources. $2^{\text {nd }}$ edition. AIMS Townsville. ASEAN-Australian Marine Science Project; Living Coastal Resources.

Folke C., Pritchard L., Berkes F., Colding J., Svedin U., 2007, The problem of fit between ecosystems and institutions: ten years later. Ecol. Soc.12, 30. 
Friedman K., Chapman L., 2008, A regional approach to invertebrate export fisheries. Secretariat of the Pacific Community Policy Brief 2/2008.

Friedman K., Purcell S., Bell J., Hair C., 2008, Sea cucumber fisheries: a manager's toolbox. ACIAR Monograph No. 135.

Friedman K., Eriksson H., Tardy E., Pakoa K., 2010, Management of sea cucumber stocks: patterns of vulnerability and recovery of sea cucumber stocks impacted by fishing. Fish Fish.

Gilbert E., 2004, Dhows and the colonial economy of Zanzibar: 1860-1970. Oxford, England: James Currey Ltd.

Holling C.S., 2001, Understanding the complexity of economic, ecological, and social systems. Ecosystems 4, 390-405.

Jentoft S., Chuenpagdee R., 2009, Fisheries and coastal governance as a wicked problem. Mar. Policy 33: 553-560.

Jiddawi N.S., Öhman M.C., 2002, Marine fisheries in Tanzania. Ambio 31, 518-527.

Kinch J., 2004, A review of he Beche-de-mer fishery and its management in Papua New Guinea. National Fisheries Authority Motopure Island Research Centre, University of PNG.

Kinch J., Purcell S., Uthicke S., Friedman F., 2008a, Papua New Guinea: a hotspot for sea cucumber fisheries in the Western Central Pacific. In: Toral-Granda, V., Lovatelli, A., Vasconcellos M. (eds.). 2008. Sea cucumbers. A global review of fisheries and trade. FAO Fisheries and Aquaculture Techn. Pap. No. 516.

Kinch J., Purcell S., Uthicke, S. and Friedman, K., 2008b, Population status, fisheries and trade of sea cucumbers in the Western Pacific. In: Toral-Granda, V.; Lovatelli, A., Vasconcellos, M. (eds.). Sea cucumbers: a global review of fisheries and trade. FAO Fisheries Techn. Pap. No. 516, pp. 7-55.

Kvale S., 1996, Interviews. An Introduction to Qualitative Research Interviewing. SAGE Publications. London.

Lee K.N., 1993, Greed, scale mismatch and learning. Ecol. Appl. 3, 560-564.

Levitan D.R., Petersen C., 1995, Sperm limitation in the sea. Trends. Ecol. Evol. 19, 228-231.

Ludwig D.E, Hilborn R, Walters C., 1993, Uncertainty, resource exploitation and conservation lessons from history. Science 260, 17-36.

MacKnight C., 1976, The voyage to Maregé: Macassan trepangers in northern Australia. Melbourne, Melbourne University Press.

Massin C., Uthicke S., Purcell S.W., Rowe F.W.E., Samyn Y., 2009, Taxonomy of the heavily exploited Indo-Pacific sandfish complex (Echinodermata: Holothuriidae). Zool. J. Linn. Soc-Lond. 155, 40-59.

McClanahan T.R., Muthiga N.A., Kamukuru A.T., Machano H., Klambo R.W., 1999, The effects of marine parks and fishing on coral reefs of northern Tanzania. Biol. Conserv. 89, 161-182.

McClanahan T.R., Arthur R., 2001, The effect of marine reserves and habitat on populations of east African coral reef fishes. Ecol. Appl. 11, 559-569.

Mgaya Y., Mbaga T., 2007, Sea cucumbers in Tanzania. In: Conand C., Muthiga N. (Eds) Commercial sea cucumbers in the Western Indian Ocean. WIOMSA Book series No 5.

Ngaga, Y.M., Sharif, M.H., Makoloweka, S., 1999, Support for community-based conservation and sustainable use of natural resources in Menai Bay, Zanzibar. Mid-term evaluation final report prepared for WWF and the Commission for Natural Resources.
Ochiewo J., De La Torre Castro M., Muthama, C., Munyi, F., Nthuta, J.M., 2010, Socio-economic Features of the Sea Cucumber Fishery in Southern Coast of Kenya. Ocean Coast. Manage. 53, 192-202.

Pauly D., Christensen V., Dalsgaard J., Froese R., Torres Jr F., 1998, Fishing down marine food webs. Science 279 (5352), 860-863.

Pauly D., Christensen V., Guénette S., Pitcher T.j., Sumaila U.R., Walters C.J., Watson R., Zeller D., 2002, Towards sustainability in worlds fisheries. Nature 418, 689-695.

Peet R.K., 1974, The measurement of species diversity. Annu. Rev. Ecol. Syst. 5, 285-307.

Perry I.R., Walters C.J., Boutillier J.A., 1999, A framework for providing scientific advice for the management of new and developing invertebrate fisheries. Rev. Fish Biol. Fish. 9, 125-150.

Purcell S.W., Gossuin, H., Agudo, N.N., 2009, Status and management of the sea cucumber fishery of la Grande Terre, New Caledonia. Programme ZoNéCo. WorldFish Center Studies and Reviews No.1901. The WorldFish Center, Penang, Malaysia.

Purcell S.W., 2010a, Managing sea cucumber fisheries with an ecosystem approach. In: Lovatelli A., Vasconcellos M., Yimin Y. FAO Fish.Aquac. Techn. Pap. No. 520.

Purcell S.W., 2010b, Diel burying by the tropical sea cucumber Holothuria scabra: effects of environmental stimuli, handling and ontogeny. Mar. Biol. 157, 663-667.

Ram R., Friedman K., Sobey M.N., 2010, Impacts of harvesting and post-harvesting processing methods on the quality and value of beche-de-mer in Fiji Islands. SPC BDM Inf. Bull. 30, 21-24.

Rasolofonirina R., Mara E., Jangoux M., 2004, Sea cucumber ?shery and mariculture in Madagascar: a case study of Toliara, south-west of Madagascar In: Lovatelli C., Conand S., Purcell S., Uthicke S., Hamel J.F., Mercier A. (eds.) Advances in sea cucumber aquaculture and management. FAO Fish. Techn. Pap. No. 463, 133-149.

Riedmiller S., 1998, The Chumbe Island Coral Park Project: management experiences of a private marine conservation project. ICRI - International Tropical Marine Ecosystems Management Symp. Proc. Townsville, Australia Nov. 1998.

Rowe F.W.E., Massin C., 2006, On a new species of Actinopyga Bronn, 1860 (Echinodermata, Holothuroidea) from the IndoWest Pacific. Zoosystema 28, 955-961.

Ruitenbeek J., Hewawasam I., Ngoile M. (eds.). 2005, Blueprint 2050: sustaining the marine environment in mainland Tanzania and Zanzibar. The International Bank for Reconstruction and Development, The World Bank, Washington DC.

Schwerdtner Máñes K., Ferse S.C.A., 2010, The history of Makassan trepang fishing and trade. PLoS ONE 5(6): e11346. doi:10.1371/journal.pone.0011346

Sheriff A., 1987, Slaves, spices and ivory in Zanzibar. James Curry Oxford.

Shiell G.R., Knott B., 2008, Diurnal observations of sheltering behaviour in the coral reef sea cucumber Holothuria whitmaei. Fish. Res. 91, 112-117.

Stephenson R.L, Lane D.E., 1995, Fisheries management science: a plea for conceptual change. Can. J. Fish. Aquat. Sci. 152, 20512056.

The Environmental Management for Sustainable Development Act, 1996, Legal Supplement (Part I) to the Zanzibar Government Gazette Vol. CVI No. 5743 of $31^{\text {st }}$ of May, 1997. 
The Fisheries Act No. 8 of 1998, Legal Supplement (Part II) to the Zanzibar Government Gazette Vol. CXIV No. 6111 of $23^{\text {rd }}$ September, 1998.

The Fisheries Act, 2005, Proposed New Fisheries Act Enacted By the House of Representatives of Zanzibar.

The United Republic of Tanzania National Environmental Policy, 1997, Vice Presidents Office, Dar es Salaam December 1997.

The Zanzibar Constitution, 1984, Order, Legal Supplement (Part II) to the Zanzibar Government Gazette Vol. CX No. 5913 of $17^{\text {th }}$ of August, 2001

Toral-Granda V., Lovatelli A., Vasconcellos M., 2008, Sea cucumbers. A global review of fisheries and trade. FAO Fish. Aquac. Techn. Pap. No. 516.

Uthicke S. 1999, Sediment bioturbation and impact of feeding activity of Holothuria (Halodeima) atra and Stichopus chloronotus, two sediment feeding holothurians, at Lizard Island, Great Barrier Reef. B. Mar. Sci. 64, 129-141.

Uthicke S., Klumpp, D.W., 1998, Microphytobenthos community production at a near-shore coral reef: seasonal variation and response to ammonium recycled by holothurians. Mar. Ecol. Prog. Ser. $169,1-11$.
Uthicke S., Benzie J.A.H., 2000, The effect of beche-de-mer fishing on densities and size structure of Holothuria nobilis (Echinodermata: Holothuroidea) populations on the Great Barrier Reef. Coral Reefs 19, 271-276.

Uthicke S., Welch D., Benzie J.A.H., 2004a, Slow growth and recovery in overfished holothurians on the Great Barrier Reef: evidence from DNA fingerprints and repeated large-scale surveys. Conserv. Biol. 18, 1395-1404.

Uthicke S., O'Hara T.D., Byrne M., 2004b, Species composition and molecular phylogeny of the Indo-Pacific teatfish (Echinodermata: Holothuroidea beche-de-mer fishery. Mar. Freshw. Res. 55, $837-$ 848.

Uthicke S., Schaffelke B., Byrne M., 2009, A boom-bust phylum? Ecological and evolutionary consequences of density variations in echinoderms. Ecol. Monogr. 79, 3-24.

Walmsley S., Purvis J., Ninnes C., 2006, The role of small-scale fisheries management in the poverty reduction strategies in the Western Indian Ocean. Ocean Coast Manage. 49, 812-833.

Wolkenhauer S.M., Uthicke S., Burridge C., Skewes T., Pitcher R., 2010, The ecological role of Holothuria scabra (Echinodermata: Holothuoroidea) within subtropical seagrass beds. J. Mar. Biol. Assoc. UK, 1-9. 